\title{
Incidencia de las historias cortas en el desarrollo de la comprensión lectora en inglés.
}

\section{Incidence of short stories in the development of English reading comprehension.}

Chico Constante Ligia Adriana. ${ }^{1}$, Chamorro Ortega Cristina Paola. ${ }^{2}$ \& Robalino Araujo María Cristhina. ${ }^{3}$

Recibido: 10-11-2019 / Revisado: 01-12-209 /Aceptado: 22-12-2019/ Publicado: 04-01-2020

\begin{abstract}
.
DOI: https://doi.org/10.33262/cienciadigital.v4i1.1069

The objective of this research was to establish the incidence of short stories in the development of reading comprehension in students from seventh year of Basic Education from "San Pio X" School in Ambato city; those with a low level of reading comprehension in the English area. The study was conducted under a quantitative method, quasi experimental design applied in two pre and post- test moments by Key English Test (KET) Cambridge. To determine the statistical differences in the process of reading comprehension among groups of students, a reading project based on the use of short stories was applied; a population of 60 students, of which 30 represents the control group and the experimental group remaining. The control group was evaluated after using the textbook as the only teaching materials, while the experimental group was then evaluated after receiving classes using a manual carefully chosen short stories. The results indicate that students in the experimental group showed at the end of the

1 Escuela Superior Politécnica de Chimborazo, Facultad de Recursos Naturales, Carrera de Forestal, ligia.chico@espoch.edu.ec

${ }^{2}$ Escuela Superior Politécnica de Chimborazo, Facultad de Recursos Naturales, Carrera de Forestal, cristina.chamorro@espoch.edu.ec

${ }^{3}$ Escuela Superior Politécnica de Chimborazo, Facultad de Recursos Naturales, Carrera de Agronomía, cristhina.robalino@espoch.edu.ec
\end{abstract}


project, a remarkable development in reading comprehension through increased capacity of reading comprehension, vocabulary, detailed and comprehensive understanding. Therefore, through this research, it was determined that the use of short stories directly influences the development of reading comprehension, and requires teachers to start using short stories as supporting the teaching - learning English.

Keywords: Short stories, reading comprehension, vocabulary, detailed and comprehensive understanding.

\section{Resumen.}

El objetivo de la presente investigación fue establecer la incidencia de las historias cortas en el desarrollo de la comprensión lectora en los estudiantes de séptimo año de la Unidad Educativa "San Pio X" de la ciudad de Ambato; quienes presentan un bajo nivel de comprensión lectora en el área de inglés. El estudio se realizó bajo un método cuantitativo, con diseño cuasi experimental aplicado en dos momentos pre y post test, mediante el Key English Test (KET) de Cambridge. Para determinar las diferencias estadísticas en el proceso de comprensión lectora entre los grupos de estudiantes, se aplicó un proyecto de lectura basado en la utilización de historias cortas; a una población de 60 estudiantes, de los cuales 30 representan el grupo control y los restantes el grupo experimental. El grupo de control fue evaluado después de haber utilizado el libro de texto como único material de enseñanza, mientras que al grupo experimental se evaluó luego de haber recibido clases utilizando un manual de historias cortas escogidas cuidadosamente. Los resultados indican que los estudiantes del grupo experimental demostraron al final del proyecto, un desarrollo notable en la lectura comprensiva a través de una mayor capacidad de comprensión lectora, vocabulario, entendimiento detallado y general. Por lo tanto, a través de esta investigación, se pudo determinar que el uso de historias cortas influye directamente en el desarrollo de la comprensión lectora, y se requiere que los maestros comiencen a utilizar historias cortas como un apoyo al proceso enseñanza - aprendizaje del inglés.

Palabras claves: Historias cortas, comprensión lectora, vocabulario, entendimiento detallado y general.

\section{Introduction.}

All around the world English is considered the main language of international business. That is why Education worldwide is working hard to improve English language learning in their schools (Lasagabaster \& Sierra, 2009). Students need to understand and use English to face globalization. The students' ability in mastering English cannot be separated from the process of reading. According to Khatib (2012) reading is the most important instrument for 
academic settings. Therefore, Tiara (2018) concludes that reading is one of the most important aspects that must be achieved by students to learn other skills. In that, the students need to learn reading comprehension to increase their perception and knowledge using effective readings to stimulate students in learning a second language. Learning reading, in fact, has become a big problem for most Ecuadorian students. If their reading comprehension is not well performed, they will not be able to communicate with foreigners or to face global competition.

Ruiz (2019) in her thesis said that Ecuador is placed in one of the last positions in the ranking of reading habits in Latin America and the Caribbean, an Ecuadorian reads a half book per year. Some reasons are that Ecuadorians do not like reading, they are not interested in reading activities and they do not do it due to the lack of time. Other reasons may be that they are not accustomed to, and the reading behavior has not been passed from generation to generation.

There are few opportunities to use short stories for reading comprehension. This becomes a great disadvantage for language learners because teachers are limited to the use of school texts, leaving aside the use of extra reading materials there is a difficulty on teaching vocabulary comprehension. Short stories texts expose learners to fresh themes and unexpected language. Pourkalhor \& Kohan (2013) added that using short stories make students feel more relaxed and easier reading comprehension. Besides that, using short stories requires more attention in order to develop students' thinking skills. In addition, Erkaya (2003) mentioned that each short story usually has a beginning, middle and an end. This will motivate and encourage every student in the classroom to continue reading to follow the plot of the story or to answer questions.

On the other hand, Bartan, Özgür Sen (2017), in the work titled "The Effects of Reading Short Stories in Improving Foreign Language Writing Skills”. It is a quasi-experimental 13week field study which was implemented in a primary school. The purpose of this study is to investigate if there is a significant difference in the pre and post-test writing achievements of students who were taught through the Read for writing model between the experimental group and the control group. Finally, the participants' views on the model were determined. Both qualitative and quantitative data collection and analysis techniques were designed such as tests for short stories, story assessment control lists, reading and writing syllabuses, lesson plans, an analytic story assessment rubric, and a student's view questionnaire. The results of the study reflect:

There are statistically significant achievements based on texts' language, content, organization, and communicative achievements.

- Another important finding was that reading short stories through Read for Writing model had an impact on improvement of writing skills, in terms of language, content, organization, and communicative achievements

- Increased confidence in enjoyment of reading and vocabulary acquisition 
Students created and developed critical thinking and writing skills, and they were highly motivated.

Literature is a body of written works, imaginative works of poetry and prose distinguished by the intentions of their authors (Rexroth, 2019)

Literature to be "writings having excellence of form or expression and expressing ideas of permanent or universal interest and a written work with a high quality and ideas of lasting and widespread interest" (Webster, 2019)

According to Steen (1999) literary genre is a category of literary composition. Genres may be determined by literary technique, tone, content, and fiction length.

Khatib (2013) argues that reading is an excellent source of comprehensible input that enhances second language acquisition. Furthermore, reading short stories can develop reading comprehension easily for learners'. Ceylana (2016) said that short stories have one plot and a few characters, or there is no detailed setting or description. Therefore it can be concluded, that the short stories can be used with all levels, all and all classes.

According to Adyana (2016), the words selection is the highest increasing, which is an aspect of the use of the short story in developing the students' vocabulary to write narrative texts. In order to the words selection, the students must multiply their vocabulary to improve their learning in four English skills. Furthermore, Khatib (2013) argue that SSBLT (Short Story based Language Teaching) is a humanistic literature based on language teaching method which aims to promote the learners ' personal, cultural and linguistic awareness. In addition, a short story usually focuses on one plot, one main character or with a few additional minor characters, and one central theme. Therefore it can be concluded, that the short story is the most appropriate to learn reading comprehension.

Language promotes some skills that a person must learn to achieve integrated language skills. If people want to learn English, they will manage the four skills the receptive skills, listening and reading, and productive skills speaking and writing (Ivancic \& Mandic, 2014).

\section{Methodology.}

This study was lead to use a quantitative approach. First, this research framed a delimitation of the problem. This means that the setting is specific and limited at the beginning of the study. Second, the hypothesis is previously established. Thus, this investigation has a hypothesis before the data collection. Finally, the data collection is measurable, as well as the results are analyzed through statistics. The following research is led by the quasiexperimental design of investigation. It is carried out in two groups, the control and the experimental. Both groups has similar features. One group follows the intervention plan and 
the other one does not. At the end of the intervention plan, the results are compared and analyzed.

This study started with a descriptive level of research. Initially, it analyzed each variable independently through the literature presented in the theoretical framework. Furthermore, the two variables were detected by some other researchers so there is data in which this study was based on. Then, it measured the dependent variable through evaluation tools. According to Hernández, Fernández \& Baptista (2010), the purpose of the descriptive level is measuring the two variables individually. An Additional reason why this research started with this level of research is that the results of the pre and post-tests were associated and analyzed.

Additionally, this investigation got to a second level, this is the correlational research. Thus, it determined if the independent variable, short stories, influences the dependent variable, reading comprehension. This level of study allowed the researcher to know if there is any relation between the two variables. Seventy (70) students were the population of this study. They were students of the seventh levels, parallels " $A$ " and "B" at Unidad Educativa San Pio X" the experimental group, and "B" the control group. There were thirty-five students (35) in the experimental group as well as thirty-five students (35) students in the control group. Being a total of seventy students as participants in this inquiry. Therefore, a sample was not necessary due to the fact that the population is not very big.

Table 1. Features of the students in both groups

Features of the students in both groups

- Male and female

- Different ages (children)

- Most of them are from Ambato, a few from different cities.

Source: Direct Research

Author: Chico L. (2018)

Both groups, the experimental group and the control group took the pre-test and post-test, nonetheless only the experimental group experienced learning to reading comprehension using short stories presented in the intervention plan. The researcher employed the following instruments for the effectiveness of this inquiry: questionnaire, pre-test and post-test, reading comprehension rubric.

This questionnaire is structured to obtain students perception of short stories. These questions contained a grammar component, necessary to assess if exposure of short stories develop reading comprehension. There are 5 questions to ask aspects such as: motivation, understanding, interest and recognizing details in reading texts; the questions were close ended questions using the Likert's scale with 3 adverbs of frequency to know (always, sometimes and never) students’́ opinion. 
As Hammersley (2005), this research technique is aimed at a representative sample of our target audience. The pretest was designed to measure the dependent variable and to know the level of students' reading comprehension. That is why it was made along with the objectives and the operationalization of variables of this inquiry. It is important to mention that it was taken from the Cambridge English: KEY (KET), and it was validated by three experts of the area of linguistics. It has five parts and thirty five items that allowed measuring the reading comprehension, vocabulary, general understanding and detailed understanding. The students had 80 minutes to read the text, analyze it and answer the questions. The teacher checks it to get students grades thought a rubric.

Hammersley (2005) post-test this type of test allows us to evaluate different aspects of the study executed. It measures the effectiveness of the same test (KET). The post-test was designed with very similar questions to the pretest with slight changes. It was taken from Cambridge English: KEY (KET), that allows measuring reading comprehension, vocabulary, general understanding and detailed understanding.. It lasted 80 minutes to read the text, analyze it and answer the questions. Additionally, it went along with the objectives and operationalization of the dependent variable of this inquiry.

Due to the fact that the dependent variable of this research is the reading comprehension skill, a rubric was used. It was taken from the Literacy Department page. It allowed measuring each participant's performance on the reading comprehension, vocabulary, general understanding and detailed understanding. Through the rubric, each participant has a grade in both the pretest and posttest. This grade would permit to compare the results of the pretest and post-test.

\section{Result.}

\section{Differences Data Collection Control And Experimental Group}

Table 2. Data collection control and experimental group

\begin{tabular}{cccccccc}
\hline & \multicolumn{3}{c}{ CONTROL GROUP } & \multicolumn{3}{c}{ EXPERIMENTAL GROUP } \\
\hline No. & Pre-Test & Post-Test & Differences & No. & Pre-Test & Post-Test & Differences \\
\hline 1 & 5 & 8 & 3 & 1 & 6 & 12 & 6 \\
2 & 5 & 7 & 2 & 2 & 8 & 11 & 3 \\
3 & 7 & 9 & 2 & 3 & 4 & 10 & 6 \\
4 & 5 & 9 & 4 & 4 & 8 & 11 & 3 \\
5 & 5 & 9 & 4 & 5 & 6 & 9 & 3 \\
6 & 6 & 10 & 4 & 6 & 8 & 9 & 1 \\
7 & 5 & 9 & 4 & 7 & 6 & 12 & 6 \\
8 & 11 & 8 & -3 & 8 & 6 & 10 & 4 \\
9 & 9 & 8 & -1 & 9 & 8 & 8 & 0 \\
10 & 6 & 7 & 1 & 10 & 5 & 11 & 6 \\
& & & & & & & \\
\hline
\end{tabular}




\begin{tabular}{cccccccc}
11 & 11 & 10 & -1 & 11 & 8 & 11 & 3 \\
12 & 10 & 9 & -1 & 12 & 7 & 10 & 3 \\
13 & 5 & 8 & 3 & 13 & 7 & 12 & 5 \\
14 & 6 & 10 & 4 & 14 & 5 & 12 & 7 \\
15 & 6 & 8 & 2 & 15 & 8 & 10 & 2 \\
16 & 6 & 10 & 4 & 16 & 8 & 11 & 3 \\
17 & 8 & 8 & 0 & 17 & 9 & 11 & 2 \\
18 & 7 & 7 & 0 & 18 & 9 & 11 & 2 \\
19 & 9 & 8 & -1 & 19 & 8 & 11 & 3 \\
20 & 8 & 7 & -1 & 20 & 6 & 12 & 8 \\
21 & 9 & 9 & 0 & 21 & 9 & 11 & 2 \\
22 & 9 & 8 & -1 & 22 & 8 & 11 & 3 \\
23 & 8 & 8 & 0 & 23 & 6 & 11 & 5 \\
24 & 12 & 8 & -4 & 24 & 8 & 11 & 3 \\
25 & 9 & 8 & -1 & 25 & 9 & 11 & 4 \\
26 & 8 & 7 & -1 & 26 & 7 & 11 & 4 \\
27 & 7 & 8 & 1 & 27 & 7 & 11 & 4 \\
28 & 8 & 7 & -1 & 28 & 10 & 10 & 0 \\
29 & 9 & 8 & -1 & 29 & 7 & 11 & 4 \\
30 & 6 & 9 & 3 & 30 & 7 & 11 & 4 \\
$\mathrm{x}$ & 7.17 & 8.00 & 0.83 & $\mathrm{x}$ & 7.03 & 10.43 & 3.4 \\
\hline
\end{tabular}

Source: Direct Research

Author: Chico, L. (2018)

Table 3. Comprehension

\begin{tabular}{ll}
\hline Pre-test control & 1,90 \\
\hline Pre-test experimental & 1,90 \\
Post- test control & 1,97 \\
Post- test experimental & 2,57 \\
\hline
\end{tabular}

Source: Direct Research

Author: Chico, L. (2018)

\section{Analysis and Interpretation}

In the question about comprehension in the pre-test, the average of the 30 students in the control group is 1,90 and the average of the experimental group in this question is 1,90 . These values show that both groups had the same average regarding comprehension in the pre-test. Similarly, the average in the post-test of the control group is 1,97 and the average of the experimental group is 2,57. Thus, these values show that there was an increase of 0.60 after the application process for the average in the experimental group. 


\begin{tabular}{ll}
\multicolumn{2}{c}{ Table 4. Vocabulary } \\
\hline Pre-test control & 1,87 \\
\hline Pre-test experimental & 1,87 \\
Post- test control & 1,93 \\
Post- test experimental & 2,70 \\
\hline
\end{tabular}

Source: Direct Research

Author: Chico, L. (2018)

\section{Analysis and Interpretation}

In the question about vocabulary in the pre-test, the average in the control group is 1.87 and the average of the experimental group is 1,87 . These values show that both groups had the same average regarding vocabulary in the pre-test. In the same manner, the average of the post-test control is 1,93 and the average of the post-test experimental is 2,70. Consequently, these values show that there was an increase of 0.77 after the application process for the average in the experimental group.

\begin{tabular}{lc} 
Table 5. General Understanding \\
\hline Pre-test control & 1,63 \\
\hline Pre-test experimental & 1,60 \\
Post- test control & 2,00 \\
Post- test experimental & 2,57 \\
\hline
\end{tabular}

Source: Direct Research

Author: Chico, L. (2018)

\section{Analysis and Interpretation}

In the question about general understanding in the pre-test, the average in the control group is 1.63 and the average of the experimental group is 1.60. These values show that both groups had almost the same average regarding grammar in the pre-test. In the same way, the average of the post-test control is 2,00 and the average of the post-test experimental is 2,57. Consequently, these values show that there was an increase of 0.57 after the application process for the average in the experimental group.

Table 6. Detailed understanding

\begin{tabular}{ll}
\hline Pre-test control & 1,77 \\
\hline Pre-test experimental & 1,67 \\
Post- test control & 2,10 \\
Post- test experimental & 2,60 \\
\hline
\end{tabular}

Source: Direct Research

Author: Chico, L. (2018) 


\section{Analysis and Interpretation}

In the question about vocabulary in the pre-test, the average in the control group is 1.77 and the average of the experimental group is 1.67 . These values show that both groups had almost the same average regarding vocabulary in the pre-test. In the same way, the average of the post-test control is 2,10 and the average of the post-test experimental is 2,60. Consequently, these values show that there was an increase of 0.50 after the application process for the average in the experimental group.

Table 7. Average comparison

\begin{tabular}{ll}
\hline Pre-test control & 7,17 \\
\hline Pre-test experimental & 7,03 \\
Post- test control & 8,00 \\
Post- test experimental & 10,43 \\
\hline
\end{tabular}

Source: Direct Research

Author: Chico, L. (2018)

\section{Analysis and interpretation}

The average comparison figure shows that the average of the control group in the pre-test is 7,17 and the average of the experimental group in this test is 7,03. Consequently, both groups started with the same level of English knowledge. After applying short stories as a strategy to promote the reading comprehension, the experimental group got an average of 10,43. This is 2,43 points more than the average of the control group, which is 8,00 This means that both groups had an increase in the post-test, but the increase gotten in the experimental group was higher. Therefore, short stories enhanced students' reading comprehension.

\section{Hypothesis verification}

The hypothesis verification was done through the statistical test T-student. Since the population of this inquiry was small, thirty (60) students only. Hernandez et al. (2010) stated that the T-student test is a statistical test to evaluate if two groups differ between them in a meaningful way.

\section{Hypothesis verification}

H0: Short stories do not promote the English reading comprehension on learners.

H1: Short stories promote the English reading comprehension on learners.

\section{Mathematical model}

H0: $\mathrm{A}=\mathrm{B}$

$\mathrm{H} 1: \mathrm{A} \neq \mathrm{B}$ 
A: media experimental group

B: media control group

\section{Statistical model}

$$
\begin{aligned}
& \mathbf{t}=\frac{\mathrm{A}-\mathrm{B}}{\underline{\mathrm{S}}} \quad \mathbf{t}=\frac{10,43-8,00}{\underline{0,91}} \quad \mathbf{t = \underline { \mathbf { 2 , 4 3 } }} \\
& \sqrt{ } \mathrm{N} \quad \sqrt{ } 30
\end{aligned}
$$

$$
\mathrm{t}=15.18
$$

\section{Significance level}

$\mathrm{C}=95 \%$ of confidence level $\quad \alpha=0.05$

\section{Degrees of freedom}

Df $=\mathrm{n}-1$

Df $=30-1$

Df $=29$

\section{Bell curve}

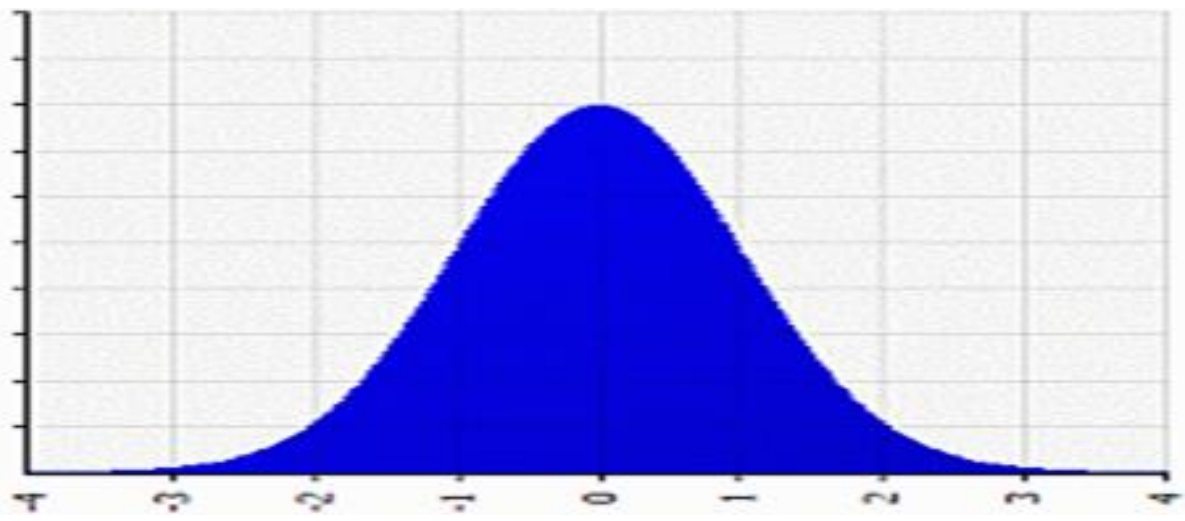

Figure 1. Bell curve

Source: Bibliographical Research

Author: Chico, L. (2018)

\section{Decision making}

Calculated $\mathrm{T}$ or statistic $\mathrm{T}$ is greater than critical $\mathrm{T} 15,18>2$, 0555). Therefore, the null hypothesis is rejected and the alternative hypothesis (Short stories improve the reading comprehension) is accepted. 


\section{Conclusions.}

- Short stories improve reading comprehension on English language learners who were studying at the Unidad Educativa SAN PIO X. The data analysis displayed that at the beginning of the English course students started with a low level on their reading comprehension, but after applying Short Stories in classes their grades improved, so their reading comprehension was improved

- A second finding was that Short stories as: Mr. Jones shop, Gladys' plane, A Small Shop, The Brown's Family has a positive effect on reading comprehension in the learners who were diagnosed. The object to claim this statement is the higher grades got in the research with the students who short stories were applied.

- A third result was that using short stories as a teaching tool students have a favorable development in English reading comprehension. The reason to claim this statement is the higher grades and the average of the experimental group got in comparison with the control group. Furthermore learners enjoyed, feel motivated.

- Finally, Short stories were detected as an effective strategy to be applied in classes because of the good grades students got and also because the researcher could define that the relation between the short stories and the reading comprehension is because understand better the vocabulary, detailed and general information in every class were short stories were used.

\section{Referencias bibliográficas.}

Adyana, R. (2016). Using short stories to enhance students' vocabulary mastery in writing narrative texts. Perpustakaan.uns.ac.id. SebelasMaret University in Surakart

Erkaya, O. (2003). Benefits of Using Short Stories in the EFL Context. Asian -efl -Journal.1. Retrieved from http://www.asian-efl-journal.com/pta_nov_ore.pdf

Ivancic, M. \& Mandic, A. (2014). Receptive and productive language skills in language teaching. English Department English Language Teaching Methodology. Retrieved from https://www.academia.edu/15220943/Receptive_and_productive_language_skills_in_langu age_teaching

Khatib. M. (2012). Enhancing Reading Comprehension through Short Stories in Iranian EFL Learners. Theory and Practice in Language Studies. Academic Publiser Manufactured in Finland, 2 (2) 1799-2591(2), 01-12.

Khatib, M. (2013). Short Story Based Language Teaching (SSBLT): A literature-based Language Teaching Method. International Journal of Basic Sciences \& Applied Research, 2(2) 155-159. http://www.isicenter.org/fulltext/paper-49.pdf

Lasagabaster, D., \& Sierra, J. (2009). Language attitudes in clil and traditional efl classes. International CLIL Research Journal, 1(2), 4-17 
Pourkalhor, O., \& Kohan, N. (2013). Teaching Reading Comprehension through Short Stories in Advance classes. asian journal of social sciences \& humanities, 2(2): 52-60. Retrieved from http://www.ajssh.leena-luna.co.jp/AJSSHPDF Rexroth, K.(2019) literture. Encyclopædia Britannica, inc.retrived fromhttps://www.britannica.com/art/literature/Literary-composition

Ruiz. M. (2019). Academic blogs to develop reading comprehension in students from superior education. Retrieved from http://repo.uta.edu.ec/bitstream/123456789/29275/1/Ruiz\%20Mercedes.pdf

Steen, Gerard1999 Genres of discourse and the definition of literatureDiscourse Processes https://www.researchgate.net/publication/254302202_Genres_of_discourse_and_the_defini tion_of_literature-

Tiara. P.( 2018)The use of Short Story as Materials in Reading

Webster, M. (2019) The 11th edition of Merriam-Webster's Collegiate Dictionary. Retrived from https://www.merriam-webster.com/dictionary/literature 


\section{PARA CITAR EL ARTÍCULO INDEXADO.}

Ligia Adriana, C. C., Cristina Paola, C. O., \& Robalino Araujo , M. C. (2020). Incidencia de las historias cortas en el desarrollo de la comprensión lectora en inglés. Ciencia Digital, 4(1), 72-84. https://doi.org/10.33262/cienciadigital.v4i1.1069

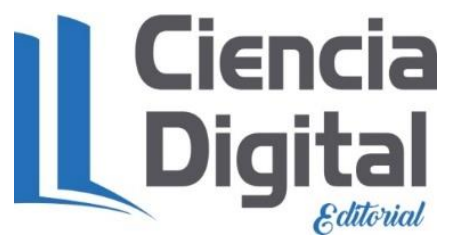

El artículo que se publica es de exclusiva responsabilidad de los autores y no necesariamente reflejan el pensamiento de la Revista Ciencia Digital.

El artículo queda en propiedad de la revista y, por tanto, su publicación parcial y/o total en otro medio tiene que ser autorizado por el director de la Revista Ciencia Digital.
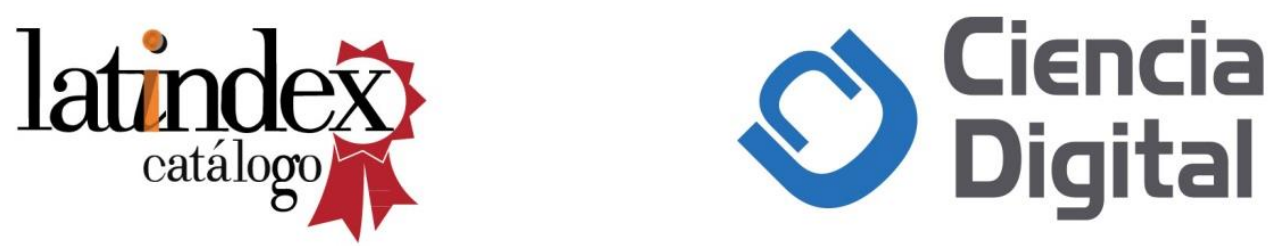